\title{
»Prøv det«
}

\section{- et plædoyer for \\ kollegial supervision}

\section{Af Henrik Rye Moller, ekstern lektor, Afdeling for Tysk, CBS og Mette Skovgaard Andersen, konstitueret lektor, Afdeling for Tysk, CBS.}

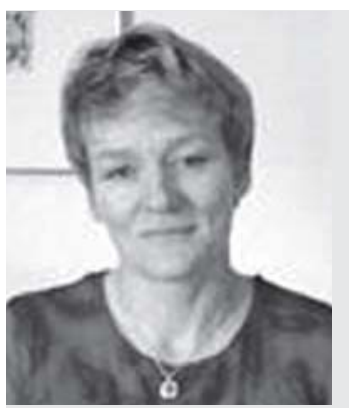

Mette Skovgaard Andersen er konstitueret lektor ved CBS, indtil for nylig ansat ved FIRST, Institut for Fransk, Italiensk, Russisk, Spansk og Tysk, og nu ansat ved det nyoprettede institut IKK, Institut for Internationale Kultur- og Kommunikationsstudier. Hun er ph.d. og adjunkt fra CBS, hvor hun især har beskæf-

tiget sig med interkulturel konceptualisering på baggrund af kognitiv teori, bl.a. i forbindelse med oversættelse af metaforer. Som led i adjunktuddannelsen gennemførte hun sammen med Henrik Rye Møller det beskrevne forløb om kollegial supervision, som hun håber med tiden bliver bredt ud til at omfatte en større kreds af ansatte på CBS. Mette Skovgaard Andersen kan kontaktes på msa.first@cbs.dk

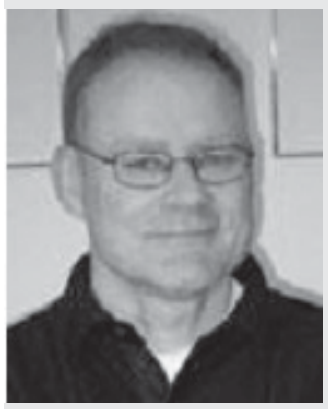

Henrik Rye Møller er informationsmedarbejder i Det TyskDanske Handelskammer og ekstern lektor ved CBS. Han er ph.d. og adjunkt fra CBS med hovedvægt på kultur- og mentalitetsstudier, og han underviser bl.a. i tysk sprogkundskab og i tyske samfundsforhold. Han har desuden undervisningserfaringer fra gymnasiet, HF og almen voksenundervisning. Det beskrevne forløb om kollegial supervision gennemførte han sammen med Mette Skovgaard Andersen i forbindelse med adjunktuddannelsen. Henrik Rye Møller kan kontaktes på hrm.first@cbs.dk.

Artiklen omhandler et konkret supervisionsforløb på en højere loreanstalt og skal, som titlen antyder, ses som en inspirationskilde for universitetslarere, der ønsker at prove krofter med den kollegiale supervisionsform. Artiklen er praksisorienteret og forsøger at påvise opnået erkendelse hos de superviserede på baggrund af sproglige iagttagelser.
Alle, der har har undervist på en højere læreanstalt, vil formentlig nikke genkendende til en beskrivelse af jobbet som et næsten privat anliggende mellem de studerende og underviseren. Kun sjældent tales der på universitetsgangene og i kollegiale sammenhænge om undervisningens glæder og frustrationer, og det er et fătal af undervisere, der har oplevet at have kolleger siddende $\mathrm{i}$ deres undervisning med det formål alene at blive klogere på egen undervisning. Der føres en »lukket-dør-politik« og undervisningskortene holdes tæet til kroppen måske ud fra devisen »undervisningen er min egen sag«. Med museskridt synes denne situation dog at være under forandring. Dette har blandt andet resulteret $i$, at undervisningskompetencer i højere grad (eller overhovedet) medvurderes ved en lektorbedømmelse, ligesom der stort set over alt er indført adjunktuddannelsesforløb med større eller mindre vægt på det pædagogiske islæt i universitetsundervisning. Med andre ord: Undervisning og pædagogik er blevet et mere »salonfähigt« emne i forbindelse med universitetsundervisning. Udviklingen går imidlertid langsomt, og der vil sikkert gå længe, før undervisningskompetencer også i praksis virkelig ligestilles med forskningskompetencer ved f.eks. lektorbedømmelser. Men den mellemliggende tid kunne så passende bruges til udvikling af og refleksion over anvendelige pædagogiske koncepter og gennemforelsesmuligheder i forbindelse med undervisningskompetencer. Denne artikel skal ses i denne sammenhæng, idet vi nedenfor vil rapportere fra et forløb med (inter)kollegial supervision, som vi gennemførte for lidt mere end et år siden med 5 yngre lærere, primært ph.d.-studerende, som led i vores egen adjunktuddannelse på Copenhagen Business School, i folkemunde Handelshøjskolen i København.

Projektet udsprang af egne oplevelser. Som nyansatte ph.d.-studerende havde vi oplevet, at undervisningen for mange af vores kolleger, der ikke tidligere havde undervist ret meget, fyldte uforholdsmæssigt meget $i$ deres bevidsthed, der jo ellers på dette tidspunkt skulle være fyldt med forskningsideer og - planer. Mange udtrykte ligeledes frustration over, at de jo ikke havde 
lært at undervise og derfor kunne have svært ved at finde ud af selv ret rutinemæssige undervisningsrelaterede fænomener. Da vi skulle i gang med vores pædagogiske forløb i forbindelse med adjunktuddannelsen, blev vi derfor ret hurtigt enige om, at vi ville lave noget, der som minimum ville kunne bruges af denne gruppe personer. Samtidig med at vi begyndte at læse os lidt ind på emnet "Deltagelse $i$ andres undervisning ${ }^{1}{ }^{1}$, deltog vi som en slags pilotprojekt $i$ hinandens undervisning for at se om dette kunne give os nogle brugbare erfaringer. På dette tidlige stade var der tale om en stort set uteoretisk tilgang til emnet, hvor vi nærmest "følte os frem«. På trods af dette gav deltagelsen $i$ hinandens undervisning i sig selv interessante og brugbare erfaringer. Selv om vi begge med henholdsvis 10 og 20 års undervisningserfaring anså os for at være relativt erfarne lærere, var der flere ting, der overraskede os. Der er 5 ting, der skal fremhæves i den forbindelse:

1) For det første syntes vi begge, at vi blev klogere på nogle af vores egne handlinger

2) For det andet viste det sig klart at være stof til eftertanke, hvor forskelligt vi oplevede/fortolkede undervisningssituationerne.

3) Derudover syntes vi på mange måder trods nogen nervøsitet over at »åbne vores undervisningsdør«, at det faktisk mere oplevedes som en lettelse end en trussel at kunne diskutere undervisningen igennem med en kollega.

4) Endelig kunne vi konstatere, hvor vigtigt det var at koncentrere sig om relativt få observationspunkter samt at kende undervisningens betingelser for at kunne være kollegaen til hjælp. Med undervisningens betingelser henvises især til formål med undervisningen generelt, med timen specifikt og de udstukne eller med de studerende forhandlede adfærdsrammer.

5) En ikke uvæsentlig erfaring var at videooptagelserne fra undervisningen var meget værdifulde i fortolkningen. Desværre måtte vi fravælge at videooptage i selve projektet, da nogle af deltagerne var nervøse for, at det skulle gøre dem unødigt nervøse. Alle var dog indforstået med, at supervisionssamtalen efter undervisningen (se nedenfor) blev båndoptaget.

På baggrund af de ovenfor nævnte erfaringer samt vores litteraturlæsning besluttede vi os for at se nærmere på muligheden for at anvende det, som nogle kalder 'interkollegial supervision', andre kalder 'supervision', 'coaching' eller 'reflekterende team' (f.eks. Poulsen, 2003) etc. som vores teoretiske tilgang. Før vi går over til at rapportere fra selve supervisionsforløbet og dets resultater, dog først et par ord om, hvordan vi bruger og forstår begrebet i denne artikel.

\section{(Inter)kollegial supervision}

Inspireret af bl.a. Per Lauvås/Camilla Rump (2001) og Helle Alrø/Marianne Kristensen (1998) ser vi den kollegiale supervision som værende forskellig fra den traditionelle pædagogiske vejledning. De adskiller sig såvel $\mathrm{i}$ form som $\mathrm{i}$ indhold fra hinanden på flere punkter.Vi sammenfatter en yderst forenklet og binær oversigt over nogle af de vigtigste forskelle nedenfor, men vil med det samme pointere, at der er tale om yderpunkter på en skala, der kan få den pædagogiske supervision til at se unødigt »sort-skole-agtig« ud. Når den alligevel medtages, er det udelukkende tænkt som igangsætter for dem, der overvejer at kaste sig ud i lignende projekter.

\begin{tabular}{|l|l|}
\hline Kollegial supervision & Pædagogisk supervision \\
\hline Form: Struktureret samtale & Form: Dialog og monolog \\
\hline $\begin{array}{l}\text { Formå: At blive } \\
\text { mere bevidst om sin } \\
\text { undervisning og opnå nye } \\
\text { handlemuligheder }\end{array}$ & Formål:At lære at undervise \\
\hline $\begin{array}{l}\text { Interkollegialt forhold: } \\
\text { Symmetrisk }\end{array}$ & $\begin{array}{l}\text { Interkollegialt forhold: } \\
\text { Asymmetrisk }\end{array}$ \\
\hline $\begin{array}{l}\text { Indhold: Bestemmes } \\
\text { i samråd men især af } \\
\text { underviser }\end{array}$ & $\begin{array}{l}\text { Indhold: Bestemmes } \\
\text { i samråd men ikke } \\
\text { udelukkende af underviser }\end{array}$ \\
\hline Produkt: Erkendelse & $\begin{array}{l}\text { Produkt: Råd - i bedste } \\
\text { tilfælde erkendelse }\end{array}$ \\
\hline
\end{tabular}

Figur 1: Kollegial versus pædagogisk supervision.

Frit efter Per Lauvås/Camilla Rump (200I)

Det vil fore for vidt at komme ind på alle forskellene, derfor skal det blot nævnes, at vi ser den kollegiale supervision som værende principielt konstruktivistisk, idet en grundforudsætning er, at vi hver især også skaber vores egen undervisningsvirkelighed, hvorfor det basalt set kun er os selv og vores egen erkendelse, vi kan bruge $i$ vores egen udvikling. Man kan i bund og grund ikke bruge andres erfaringer til noget uden $i$ hvert fald som minimum at bearbejde dem selv. Først når man selv erkender noget, bliver man i stand til at handle anderledes og på denne måde opnå læring (jf. nedenfor). Den pædagogiske supervision tenderer mod at være positivistisk, idet det antages, at andre kan lære nogen at undervise "på en rigtig måde«. Hermed tager den kollegiale supervision større højde for individualiteten, idet den i højere grad accepterer, at det, der er rigtigt for underviser $\mathrm{X}$, ikke nødvendigvis er det rigtige for underviser $\mathrm{Y}$.

\section{Supervisionsforløbet}

I forløbet deltog 5 i ansættelse yngre lærere uden nogen form for pædagogisk uddannelse samt begge adjunkter. 
Forløbet var delt op i flere faser, bla inspireret af Lauvås \& Rump (2001, 26f):

Fase 1: Kontakt og introduktionsmøde

Fase 2: Møde om undervisernes vejledningsønsker samt rollefordeling

Fase 3: Overværelse af undervisning

Fase 4: Møde med struktureret supervisionssamtale og diskussion

Fase 5: Spørgeskemaundersøgelse

Efter introduktionsmødet, hvor vi forsøgte at afmystificere projektet samt planlagde den praktiske gennemførelse, blev hver deltager bedt om at sende os en kort beskrivelse af, hvad den pågældende i særlig grad kunne ønske sig at blive klogere på i sin egen undervisning. Disse beskrivelser og ønsker blev genforhandlet og forsøgt indskrænket på det efterfølgende møde, hvor rollerne ligeledes blev fordelt, således at de deltagende superviserede hinanden i halvcirkel. Dette for at undgå muligheden for "hævnmotiver« i supervisionen. De roller, vi arbejdede med, var følgende:

1) En underviser: $U$ - hvis primære opgave det var at være åben og ærlig, eksplicitere egne ønsker, opsummere pointer samt lytte og forsøge at undgå forsvarsadfærd,

2) En kollega: K - hvis primære opgave det var at observere efter matrixen:

a. Først direkte observerbare handlinger og fænomener (f.eks. »du kigger ikke på de studerende $\ll)$.

b. Dernæst spørge ind til observationerne (f.eks. "er det med vilje«?)

c. Dernæst fortolke og konkludere (f.eks. "at du ikke kigger på de studerende, făr mig til at tro, at du er bange for dem«) og forst til sidst:

d. Eventuelt give gode råd eller opstille alternativer (f.eks. »du kunne overveje at bestemme dig for at kigge mere på de studerende«).

3) En observatør: $\mathrm{O}$ - hvis primære opgave det var at observere kommunikationen mellem K og U, stoppe den om nødvendigt og evt. opsummere, hvad der var blevet sagt. Endvidere efterfølgende deltage i fortolkningen af undervisningen.

Disse tre personroller deltog altid i undervisningen. De øvrige medlemmer af gruppen kaldes:

4) Medobservatører, $\mathrm{MO}$, hvis primære opgave det var ligeledes at observere kommunikationen mellem $\mathrm{K}$ og U samt $\mathrm{O}$ samt at bidrage til alternative fortolkninger uden at have været $\mathrm{i}$ undervisningen.

I udgangspunktet var det meningen, at adjunkterne kun skulle indtage en observatørrolle, men af praktiske grunde måtte vi undertiden desværre indtræde $i$ kollegarollen. Når dette beklages her, skyldes det en formodning om, at supervisionen vil være mest givende, når der er størst mulig symmetri de deltagende parter imellem. Den praktiske gennemførelse viste sig i øvrigt at være langt mere kompliceret, end antaget. Alene at finde tid til at mødes alle 7, eller mulighed for at underviser $\mathrm{X}$ kunne supervisere underviser $\mathrm{Y}$ et par gange på tidspunkter, der passede begge parter, viste sig at være uforholdsmæssigt svært i en travl universitetshverdag.

\section{Formål, resultater og eksempler}

Da det er underviseren selv, der bestemmer, hvad vedkommende særligt ønsker supervision i forbindelse med, er formålet for den enkelte naturligvis at blive klogere på sin egen undervisning i relation til dette. Overordnet kan man derfor sige, at formålet med supervisionen er, at der hos underviseren opstår erkendelse og læring (jf. læringscirklen nedenfor), der medfører, at underviseren bevidstgøres om sine handlinger og enten om ønskeligt er i stand til at ændre dem eller alternativt at bevare dem som en bevidst handling. For at kunne vurdere om læring finder sted, burde man derfor $\mathrm{i}$ princippet deltage $\mathrm{i}$ efterfølgende undervisningsforløb for at se om f.eks. tidligere uønskede og uhensigtsmæssige handlinger er blevet erstattet af mere ønskede og hensigtsmæssige. Dette er en faktor, vi først er blevet opmærksomme på i vores egen læringsproces med forløbet, og som heller ikke er uproblematisk. Det er grundlæggende ikke $\mathrm{i}$ den kollegiale supervisions ånd at kontrollere, om noget er som det »skal/bør» være. Det er U's egen sag. Man kan derfor måske anse det for tilstrækkeligt, at deltagerne selv synes, de er blevet klogere, hvad alle deltagere i det efterfølgende spørgeskema tydeligt gav udtryk for. Før vi går over til et konkret eksempel på det, vi kalder for opnået erkendelse, et par ord om vores begrebsapparat.

\section{Om 'erkendelse' og 'læring'}

Når vi taler om, at nogen kan opnå erkendelse ved supervisionen, så henvises der til, at typisk underviseren, men også de øvrige deltagende parter, ved at blive konfronteret med en konkret undervisningsoplevelse efter forløb 1 i forløb 2, altså under supervisionssamtalen tvinges til at reflektere over episoder og handlinger, som tidligere måske har været ureflekterede (eller fastlåste).Vi vil her koble til David Kolbs læringscirkel (Kolb 1984). Ifølge denne er der flere forløb i læringsprocessen. 


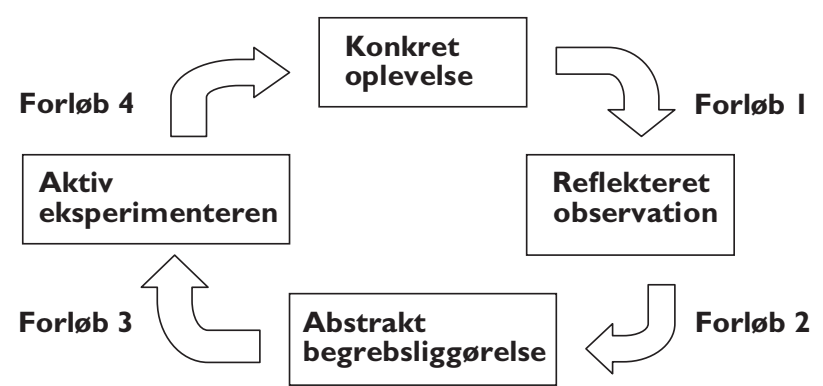

Figur 2: Kolbs læringscirkel med egne tilføjelser (Kolb 1984)

U bliver på denne måde »forstyrret« jævnfør den systemiske tankegang (Niklas Luhmann refereret i Andersen, Møller \& Villemoes 2006, Kapitel 1) i sin opfattelse af egen undervisning, og denne forstyrrelse kan måske føre til ændret handlemåde eller tankegang, i princippet først efter at oplevelsen er blevet gjort til genstand for abstrakt begrebsliggørelse (jf. forløb 3). Det vi kalder egentlig læring opstår først i det øjeblik, underviseren i forløb 4 beslutter sig for at ændre adfærd på baggrund af oplevelserne og reflektionerne.

Med hensyn til erkendelse mener vi ikke, at denne nødvendigvis behøver at være ekspliciteret. Et supervisionsforløb kan sagtens medføre tavs erkendelse, men der kan i vores forståelse ikke være tale om erkendelse, hvis den ikke kan ekspliciteres. For os som ledere af dette projekt opstår der selvfølgelig et praktisk problem i forbindelse med at sandsynliggøre, at læring har fundet sted. Det har allerede været nævnt, at den egentlige læring først vil kunne konstateres i det øjeblik, der kan iagttages ændringer $\mathrm{i}$ handling alternativt at underviseren når frem til bevidst at fastholde en hidtil ubevidst praksis. Fokuspunktet for os i nedenstående case-eksempel er derfor erkendelse, som nødvendigvis her må kobles til sproget.Vi vil med andre ord forsøge at vise, hvor i uddraget fra vores supervisionssamtale vi mener sprogligt at kunne påvise, at erkendelse har fundet sted.

\section{Case-eksempel}

U er en yngre kollega, der har nogle års undervisningserfaring bag sig. Han har ved før-supervisionsmødet givet udtryk for, at han især ønsker at blive superviseret om følgende punkter:

- Brug af overheads og samspillet mellem disse og mundtligheden/dialogen

- Strukturering af timen, formål og pointer samt fokus på disse

- Studenterinvolvering (som vi delvist fortolker som udfyldelse af lærerrolle)

Den kollegiale supervision finder sted i en dobbelttime på et 3. semesters hold i faget 'Kommunikation og feltarbejde'. Uddragene stammer fra 1. time, hvor U havde holdundervisning. I 2. time var der såkaldt klyngevejledning, hvor de studerende kunne henvende sig vedrørende et mindre kursusprojekt. I supervisionssamtalen deltager $\mathrm{U}, \mathrm{K}$, ligeledes en yngre lærer med et par års erfaring, $\mathrm{O}$ samt MO. I første uddrag drejer samtalen sig om brugen af overheads. Transskriptionen holder sig meget tæt til det talte sprog, og der er kun tilføjet regibemærkninger i kantede parenteser i de tilfælde, hvor vi har skønnet det nødvendigt. K har i uddraget netop opsummeret sin egen opfattelse af brugen af overheads. Ifølge $\mathrm{K}$ kommer overheadsene relativt tæt på hinanden, og der synes at være »ret meget pres på« i den første time. O beder om lov til at overtage K’s rolle og følgende dialog udspiller sig:
O: Jeg tænkte på - øh - lige at overtage din rolle lidt og spørge $U$ - øh - om du har overvejet, hvorfor du bruger så mange overheads?

$\mathrm{K}: \mathrm{Ja}$

$\mathrm{K}: j a$, det sagde du selv

O: Ja

O: Ja

O: Ja, er det sådan, at du føler dig mere sikker i undervisningen ved at have overheads?

O: $\mathrm{Mm}$ [stigende tonefald]

K: Det er der en, der siger
$\mathrm{U:Ja}$

U: Hm, jamen altså det, altså det fordi, altså det synes jeg er pissesvært, ik'? Fordi jeg har det nemlig nogengange også sådan at jeg føler ligesom altså på en eller anden måde, at jeg bliver lidt en slave af overheads, forstår du hvad jeg mener?

U. Nu har man lavet dem. Eller -

U:Altså det er ligesom den gyldne altså altså altså sådan en med et fint ord medieessentialisme, altså at man siger: Guldet er ligesom på overheadsene

U: Jamen, jeg synes også det er svært, fordi jeg synes ligesom at de studerende understøtter det der med, at overheadsene på en eller anden måde er omdrejningspunktet i undervisningen. Altså altså: Har du lagt det der ud på SiteScape?

U: Ja.

U: Ud, og får vi en kopi 
$\mathrm{K}: \mathrm{Ja}$

O: Mm mm mm. Men jeg hører dig ligesom sige, at du på en eller anden måde synes, at det er et problem. At du du er ikke helt sikker på, at din brug er den rigtige ... for dig

$\mathrm{K}: \mathrm{Mm}$

O: $\mathrm{Mm}$

O: Ja, ja

$\mathrm{K}: \mathrm{Ja}$

$\mathrm{K}$ : Men der bliver det så lidt komprimeret, når det er at du så synes, altså jeg oplever det sådan, at nu skal vi lige nå det

K...har du overvejet at droppe dem f.eks.? Lige de sidste fire, eller tage dem i anden lektion

$\mathrm{K}$ :Altså det kunne man, ikke også?

$\mathrm{K}: \mathrm{ja}$, ja, ja

K:.. at man er lidt slave af det

O: Så i virkeligheden kommer du til at blive lidt slave af dine overheads, som du som du selv var inde på: Er jeg slave af dem. Det føler du, du alligevel bliver i et eller andet omfang?

K: Fordi det var det, du havde planlagt

O: Nej, okey

O: Er det måske en løsningsmodel for dig at lave lidt færre

O:At du måske sagde til dig selv, i hver time må jeg højst have 8 overheads, eller hvad det nu måtte være [ler], jeg ved ikke I3 I4 I5 stykker eller sådan noget
U: Som om det ligesom er, altså ligesom det pædagogiske fokusområde

U: Men jeg kunne godt tænke mig...

U: Ja, jeg synes måske at at at for det første har jeg for mange overheads og nogle gange kan jeg også godt blive lidt træt at jeg ligesom, også fordi jeg synes det er svært nogle gange, det er en pissesvær balancegang mellem at ligesom give dem plads og sige nårm nu fortsætter vi ud at det her spor

U: og så tænker man, jeg har jo lavet de her overheads, og skal jeg ligesom køre ligesom køre det planlagte spor med de overheads jeg har lavet, eller skal jeg sige, off-road med dem $\mathrm{U}: \mathrm{Hmm}$, hvad de tænker og

$\mathrm{U}: \mathrm{Mm}$

$\mathrm{U}: \mathrm{ja}, \mathrm{ja}$

U: Jo, fordi der har jeg det sådan, der føler jeg det måske sådan, at nej jeg SKAL [med tryk] være igennem det

U: Ja, ja eller jeg føler, jeg vil jeg vil ikke forlade en time uden at jeg har eksponeret dem for nogle overheads jeg har lavet

U: Ja, for eksempel. Det kunne man. Man skulle lave færre øh men

$\mathrm{U}$ : ja, for eksempel.

$\mathrm{U}+\mathrm{K}: \mathrm{Mn}$ jo

U: For eksempel kunne man lave færre. (...)

Figur 3: Uddrag af supervisionssamtale

I ovenstående tekstuddrag er det umiddelbart brugen af overheads, der er det centrale tema.Vi ser dog i dette tilfælde denne brug som eksponent for U's strukturering af timen, som også var et af U's supervisionsønsker. U's brug af overheads har betydning både for struktureringen af timen og dialogen med de studerende. $U$ har i før-vejledningsforløbet blandt andet bedt om at blive superviseret i fht., om han i den forbindelse er en slave af overheads. $U$ har imidlertid selv svaret på dette allerede i begyndelsen af samtalen, idet han fremstiller sig selv som lidt en slave af overheads. Lidt senere i samtale udtrykker han, at han måske har lidt for mange overheads, men er selv i stand til at tale sig frem til, at disse overheads stiller ham $i$ et dilemma $i$ forhold til hans planlægning af undervisningen. Et dilemma, hvor han på den ene side synes, at han skal igennem alle sine overheads og på den anden side godt kunne tænke sig en gang imellem at lade de studerende overtage styringen lidt (eller fortsætte off-road, som han selv siger). Tilsyneladende har denne problematik ikke været ham så bevidst, før han fik lejlighed til at tale om den. Den oplagte løsning, der foreslås af $\mathrm{O}$, nemlig at lave færre overheads, synes heller ikke at have været $i$ hans overvejelse. Skiftet i modalverbet kunne antyde, at $\mathrm{U}$ i første omgang ser dette som en potentiel mulighed, der straks gøres til en aktuel mulighed for ham selv. Erkendelsen i det ovenstående kan for den mere erfarne lærer synes uendelig banal, men det er vigtigt at fremhæve, at U's erkendelse og mulighed for læring næppe ville være sket, hvis vi som erfarne lærere havde sagt til $U$, at vi syntes, at han brugte for mange overheads.

Det næste eksempel på erkendelse, vi vil fremhæve, er i forbindelse med U's lærerrolle. K har netop - så objektivt, som det er muligt for $\mathrm{K}$ - beskrevet de studerendes adfærd, der efter K's egen målestok, er yderst forstyrrende. De studerende kommer og går, tilsyneladende som de vil. De læser, SMS'er, spiser, snakker etc., uden at $\mathrm{U}$ synes at tage notits af det. $\mathrm{K}$ undrer sig over dette, og følgende dialog udspiller sig: 
O: Ja, det det går meget på det faglige

O: Ja, lige præcis

$\mathrm{K}$ : Krav fra underviserens side

O: Op- opfatter du dig selv som trådt ud af den autoritære rolle?

O: Nej, nej

$\mathrm{K}:$ Er er det bevidst?

K: Nå jo men altså

$\mathrm{K}:$ Ja, ja, ja ja

O: Men der det noget, der generer dig?

$\mathrm{O}:$.........................for en ting er, at $\mathrm{K}$ og jeg sidder lige foran salatskålen og bliver helt vildt irriteret på hende og får lyst til at sige til hende:

K: [siger noget uhørligt] Ja, ja, ja

O: Helt ærligt, kan du ikke lige tage lige og slappe lidt af. Men at hvis om mm det er noget, om det er noget, der generer dig, så kunne du måske overveje, om der var en anden måde du kunne gøre ... det på ... uden at være autoritær, men men

$\mathrm{K}$ : Mobiltelefoner ringer midt i det hele og en forlader lokalet

O: Men på en eller anden måde markerer dine grænser. $\mathrm{K}$ :Altså, nu er vi jo også kommet ind $\mathrm{i}$ en lektion, der er $\mathrm{i}$ et forløb, hvor vi vi har ikke været med hele vejen, og fra starten og sådan noget, fordi jeg sad da også og tænkte på, om I måske i allerførste dobbeltlektion havde [pause] fordi nogle undervisere starter jo lige med at sige, hvad spillereglerne er her hos mig. Altså, hvor hård er man, hvor blød er man. Altså der vidste jeg jo ikke, der havde jeg jo også lyst til at spørge $U$ om, fordi så synes jeg, det det kunne sætte det lidt i relief, altså har du haft det, ja?

O: Det kan du jo spørge $U$ om

$\mathrm{K}:$ Ja, har du har du haft sådan noget?

$\mathrm{K}:$ Ja, altså lige ridse op

K:Altså det kunne jo godt være du havde sagt til dem, det generer mig ikke, I skal bare

Eller jeg er den type, der ikke lader mig gå på af det og det ... det vidste jeg ikke

$\mathrm{K}:$ Okey

K: Ja.....Ja, ja

O: Så det var måske en ide at arbejde videre med. At kridte banen op fra starten og sige prøv lige at høre her:Jeg har det sådan, at jeg kan ikke fordrage, at folk de spiser i mine timer, jeg kan ikke fordrage, at de SMS'er i mine timer [griner] jeg kan ikke fordrage, at de sidder og kontakter hinanden, og jeg kan ikke fordrage, at de kommer for sent

\section{$\mathrm{K}: \mathrm{Mm}$}

U: Ja, og så synes jeg måske, så kunne man diskutere, det som jeg godt kunne tænke mig at diskutere, er øh det ved jeg ikke altså sådan generelt sådan den grundlæggende disciplinære disciplinering af dem, $\mathrm{mm}$ ik'?

U:Altså hvad fanden. Altså skal jeg. Skal man, hvad skal man gøre. Skal man sige til hende der salatskålen [en bestemt studerende], [ler] nu må du altså lige, æh eller eller der bliver ikke SMS'et her. Jeg er jo ikke sådan, som underviser altså der er jeg jo totalt trådt ud af den der autoritære rolle, jeg er jo ikke sådan en, der står og knalder døren i hovedet på dem eller det er ikke - det mener jeg ikke

$\mathrm{U}$ : Ja, eller jeg går i hvert fald ikke ind og konfronterer dem med det og siger I må ikke SMS eller

U: [Pause] Lige altså jeg ved ikke om det er bevidst, men det er ligesom

U: Jeg har bare tænkt at at at at sådan har jeg det med sådan en højere lære..

U: Det kan ligesom ikke være min opgave og altså det er frivilligt, altså de, døren er åben og hvis de vil lave noget andet i deres liv, så..

U: Mmmm, ja altså det generer mig lidt, altså jeg synes at, $\mathrm{U}: \mathrm{Mm}$

$\mathrm{U}: \mathrm{Mm} \mathrm{mm} \mathrm{mm}$

U: Det kunne godt være man skulle..

U: Ja, ja men det generer mig, det er da, det generer mig lidt, det der sådan noget med det der med at folk de kommer og går og sådan noget, ikke?

U: På en eller anden måde gør det da.

$\mathrm{U}: \mathrm{Mm}$

U: ja, ja, lige præcis, ja

U: Nej, men det ville være. Det tror jeg kunne være en god ide at lave sådan en kontrakt eller sådan noget og sige

U:Altså nu.. jeg forventer, at det ikke min I har forberedt jer og at I der bliver ikke talt i mobiltelefoner. Det kunne man jo godt gøre

U: Nej, men det har jeg ikke

$\mathrm{U}: \mathrm{Nej}$

$\mathrm{U}: \mathrm{Ja}$

U: Men det var en det var rent faktisk en god ide, synes jeg

U: Sige: Jeg gider ikke det der

$\mathrm{U:} \mathrm{Ja}$

$\mathrm{U}:$ Nej, nej

U: Ja, fordi jeg har også haft nogle timer, hvor sådan, hvor der er folk, der sådan begynder at sidde at sidde og snakke lidt og der ved jeg ikke, jeg gid.., skal man også sådan skal man så SHH [tysselyd], eller altså

U: skal man gøre, altså, det ved jeg ikke: Gør I det? [altså tysser] Forstår I sådan, eller 
I dette uddrag udtrykker U stor usikkerhed om sin lærerrolle. Usikkerheden går især på det, U selv kalder den disciplinare disciplinering af de studerende og henviser til de studerendes adfærd, og hvor vidt denne adfærd generer undervisningen. $U$ har tilsyneladende truffet en beslutning om ikke at være autoritær, idet han er totalt trådt ud af den autoritare rolle, og da denne beslutning $i$ hvert fald i U's egen optik er uforenelig med nogen som helst markering af adfærdsgrænser, kan det se ud som om, $U$ ikke vil lade sig forstyrre af de studerendes adfærd. Denne beslutning synes dog svær at holde fast $i$ for $U$ under dialogen. $U$ åbner selv emnet, hvad vi fortolker som begyndende erkendelse af, at de studerendes adfærd kan være generende (i parentes bemærket ikke kun for U men i lige så høj grad for de studerende). Dette nævner U efterfølgende flere gange under dialogen. Midt i uddraget synes der at komme en form for løsningsmodel, idet $U$ tager ideen om en form for kontrakt med de studerende til sig. Tilsyneladende er der dog ikke tale om en brugbar erkendelse endnu, da $U$ - som det ses i slutningen af uddraget - med sit spørgsmål Gor I det? vender tilbage til problematikken for at afsøge de øvrige deltageres grænser. I den efterfølgende dialog, som ikke er gengivet her, kommer begreberne 'autoritær' versus 'autoritativ' til diskussion. Disse begreber synes at hjælpe $U$ til yderligere at erkende, at det er muligt at afstikke adfærdsrammer som underviser, uden at man nødvendigvis er autoritær. $U$ opsummerer selv således:

U: Altså jeg kan også lige.. bare prøve.. jeg vil godt lige samle op. Altså færre overheads ik'? Og gøre diskussionen [pause], være lidt mere modig med at kaste mig ud i de der..altså diskussioner med dem, kan man sige, og så kan man sige ... diskussionen omkring hele det der altså det disciplinære, en kontrakt f.eks. ikke --og sige, det gider jeg altså ikke.

Vi har ovenfor givet et par eksempler på, at den kollegiale supervision synes at kunne give erkendelse, man måske kun med møje ville være kommet frem til uden supervisionssamtalen. I de ovenstående eksempler er der tale om ekspliciteret erkendelse, idet $U$ flere gange selv italesætter, hvad der synes at være pointer i det pågældende tilfælde. Der er imidlertid rigtig mange eksempler på, at U kun samtykker med et 'Mm'. Vi tolker disse 'Mm'-er dels som 'gambits', der holder samtale i gang, men også som samtykke-erklæringer. Det gør vi primært på baggrund af de opsummeringer, U laver, der som i ovenstående tilfælde kan tolkes som tegn på, at $U$ er nået frem til erkendelse.

\section{Afsluttende bemærkninger}

Vores overordnede formål med denne artikel var at inspirere andre undervisere på de højere læreanstalter til at prøve kræfter med den kollegiale supervision.Vi mener, at denne supervisionsform har oplagte fordele og store potentialer netop på de højere læreanstalter, hvor mange undervisere traditionelt har været ret lukkede omkring deres undervisning. Ved at tage udgangspunkt i underviserens egne ønsker og behov undgår man i vid udstrækning fornemmelsen af kontrol, som mange universitetslærere ellers ofte reagerer imod. Som sideeffekt får man måske oven i købet åbnet en pædagogisk debat, hvad der også kan synes at være en mangelvare på mange institutioner.

Skal vi konkludere på forløbet, mener vi, at der er flere muligheder end begrænsninger, men naturligvis er der faldgrupper. Lad os derfor opsummere vores vigtigste erfaringer om 1) deltagerforudsætninger 2) selve supervisionen samt 3) det interkollegiale forhold:

Hvad angår 1) deltagerforudsætningerne, vil det være det bedste udgangspunkt, hvis alle deltagerne har gennemgået en form for pædagogisk grunduddannelse. Rene teknisk-pædagogiske emner egner sig dårligt til den kollegiale supervion. I ovenstående eksempel med overheads er der f.eks. en lang udeladt snak, der egentlig blot handler om, hvor overheadprojektoren skal placeres for at give optimalt udsyn for de studerende, og hvor U bør placere sig i forhold til denne. Der er ingen grund til at lade en sådan problemstilling blive genstand for en diskussion, da der er tale om - sådan som vi ser det - teknikaliteter, hvis diskussion ikke giver større indsigt. Men grænserne mellem form og indhold er selvfølgelig flydende, hvad vi også kan se af ovenstående dialog vedrørende brug af overheads.

Hvad angår 2) selve supervisionen, er det vigtigt at fremhæve, at det er nødvendigt at introducere ordentligt til supervisionsteknikker og tankegangen i den kollegiale supervision for at fă det bedst mulige resultat. Som ledere af projektet måtte vi - hvad der også fremgår af tekstuddragene - flere gange gribe ind i dialogen, især fordi $\mathrm{K}$ ofte sprang direkte til konklusionerne og dermed ikke ekspliciterede de mellemliggende trin, således at det blev tydeligt for $\mathrm{U}$, på hvilket grundlag $\mathrm{K}$ mente noget.

Sidst men ikke mindst så mener vi, at det er alfa og omega, at der i 3) det interkollegiale forhold hersker en stor grad af tillid og fortrolighed parterne imellem. Det skal derfor kort nævnes, at den kollegiale supervision næppe kan være et egnet instrumentarium i forbindelse med f.eks. klagesager, hvor det interkollegiale forhold er kendetegnet af asymmetri mellem $\mathrm{U}$ og K. Tillid og fortrolighed er formentlig nemmest at opnå, hvis $\mathrm{U}$ og $\mathrm{K}$ befinder sig mere eller mindre på samme erfaringsniveau rent undervisningsmæssigt, hvorfor vi ser dette som en fordel. At vi tror, at det bedst mulige resultat opnås, hvis det interkollegiale forhold er jævnbyrdigt, skyldes endvidere vores egen erfaring. Vi oplevede undervejs i forløbet flere gange eksempler på, at vi selv som mere erfarne undervisere kunne have svært ved ikke at "øse ud af vores erfaring". De problemer og spørgsmål, de involverede undervisere havde, var selvfølgelig præget af deres relativt korte 
undervisningserfaring og kunne synes ret banale, som vi også har været inde på. Men det er vigtigt at indse, at disse problemer jo netop ikke var banale for underviserne selv, men simpelthen de problemer, de aktuelt oplevede. Bemærkninger som »det er et typisk problem for nye lærere«, "jeg plejer selv at.." osv. vil derfor ikke umiddelbart hjælpe underviseren, men måske i værste tilfælde få underviseren til at føle sig mere usikker i underviserrollen end før supervisionen.

Men når dette er sagt, så mener vi ikke, at det kan gå hurtigt nok med at komme i gang.Vi lærte selv en masse, fik afmystificeret "det farlige $i$ at dele undervisning med andre« og allerbedst hjulpet et par kolleger i gang med selvrefleksionen og de pædagogiske diskussioner, hvilket de også alle udtrykte stor tilfredshed med i den afsluttende evaluering. Den kollegiale supervision bør være en integreret del af universitetslærerens dagligdag på alle niveauer, prøv det!

\section{Litteratur}

Andersen, Mette Skovgaard/Møller, Henrik Rye/Villemoes, Anette (red.)(udkommer i 2006), Fra tekst til samfund - tur-retur, Samfundslitteratur, København.

Alrø, Helle/Kristensen, Marianne (1998), Supervision som dialogisk lareproces, Aalborg Universitetsforlag, Aalborg.

Kolb, David (1984), Experiental Learning, Englewood Cliffs, Prentice Hall.

Lauvås, Per/Rump, Camilla (2001), Vor falles viden, Samfundslitteratur, København.

Poulsen, Sten Clod (2003), Ledelse af selvstyrende larerteam/Ledelse i selvstyrende laererteam, MetaConsult Forlag, Slagelse.

\section{Noter}

1 Vi læste bredt om kollegial supervision/vejledning, bl.a. i gymnasie-/folkeskolesammenhænge, men er naturligvis især inspireret af forløb på universitetsniveau (f.eks. på Københavns Universitet og på Århus Universitet). Som andre, der beskæftiger sig med emnet, ser vi grundlæggende kollegial supervision $i$ et systemisk perspektiv baserende på et erfaringsbaseret læringssyn. 